\title{
Predictors of Entrepreneurial Mindset among University Students
}

\author{
Zaidatol Akmaliah Lope Pihie ${ }^{1}$, Keetanjaly Arivayagan² \\ Faculty of Educational Studies, University Putra Malaysia, Malaysia \\ zalp@upm.edu.my ${ }^{1}$,keetanjaly@gmail.com ${ }^{2}$
}

\begin{abstract}
Entrepreneurship Education (EE) is a learning process of developing learners' skills and mindset, which creates a pathway to transform creative ideas into entrepreneurial action. In today's tumultuous working environment, it is important for university students to gain entrepreneurship experience before graduating as many employers are seeking for students with entrepreneurial mindset. This is essential because students who have an entrepreneurial mindset are accountable for their own actions, brings new perspectives and youthful ideas into the workplace. Hence, this study explores the significant predictors of university student's entrepreneurial mindset. This study endeavoured to answer the research questions through employing quantitative research method. The data was gathered by using simple random sampling, which consists of 366 university students. Findings indicated that University students have moderate level of entrepreneurial mindset and discovered that the level of self-entrepreneurial competencies was overall moderate level. The findings also found out a high correlation between self-entrepreneurial competencies with entrepreneurial mindset, followed by regression analyses revealed that risk propensity, creativity, planning and financial literacy are the significant predictors for university student's entrepreneurial mindset. The results from this study provide indepth insights about university students' entrepreneurial mindset and create a delineate directions for further research and analyses. Implications and recommendations of the findings are presented in the paper.
\end{abstract}

Keyword: Entrepreneurial mindset, Self-entrepreneurial competencies, University students

\section{INTRODUCTION}

Entrepreneurship, is widely acknowledged as an important growth strategy for sustaining the country's economic growth (Israel \& Johnmark, 2014), particularly in career perspectives and business opportunities which generate profits (Gurol \& Atsan, 2006; Othaman, Ghazali \& Cheng, 2005). Viewed in this context, successful entrepreneurs contribute towards the development of society and advancement of economic growth (Wu, 2009). These resulting new entrants into the entrepreneurial industry are generating intense competition, which requires learners to adopt entrepreneurial mindset to survive the competition. While this account for the overwhelming majority of colleges and universities around the world to offer entrepreneurship courses (Fayolle \& Klandt, 2006) to equip students with the essential entrepreneurial knowledge and skills (Henry, 2003).

Entrepreneurship Education (EE) is a learning process of developing learners' skills and mindset, which creates a pathway to transform creative ideas into entrepreneurial action. This is vital as it triggers learner's competencies, supports personal development and enhances social inclusion as well as employability (Sözen, 2015) which eventually contribute to an entrepreneurial spirit or behaviour. $\mathrm{EE}$ is not synonymous with vocational education, nor does it mean the same thing as business education. EE is aimed to promote creativity, innovation and self-employment among students by instilling the entrepreneurial knowledge, competences and attitudes in the learners (Israel \& Johnmark, 2014).

Entrepreneurial mindset simply defined as the feelings and the belief of a particular ability to think out of the box (Lackéus, 2016; 2013). Commencing with the pioneer work of Bruyat \& Julien (2001) who discussed the idea of entrepreneurial mindset on self-competency, much research since been undertaken on the term in the context of not only self-competency but also in several other fields (Lackéus, 2015; Solesvik, et al., 2013). There is also prior research on entrepreneurial mindset research within the broader field of entrepreneur research. In view of the multidisciplinary nature of prior research, there are varying definitions of entrepreneurial mindset and it is problematic to 
determine an exact meaning of entrepreneurial mindset. However, in this study, entrepreneurial mindset is considered a holistic perception of generating novel ideas, evaluating opportunities and risks, or starting and running a business, whereby an individual internally assesses his or her perceptions based on holistic rather than functional attributes.

\subsection{Problem Statement}

The rate of unemployed among graduates has been alarming lately (Hanapi \& Nordin, 2014). According to the National Economic Advisory Council (NEAC) on the New Economic Model (NEM), in 2008, about 30\% graduates from local public universities remained unemployed for six months (NEAC, 2010). This unparalleled phenomenon for university graduates especially in public sector can be explained by the fact that wages employment or 'secure' employment is no longer a guarantee (Arokiasamy, 2010; Ooi, Selvarajah \& Meyer, 2011). As a result, the Government has endorsed the Malaysian Education Blueprint 2013-2025 policy, which emphasize on the "entrepreneurial mindset" among students and institutions urging graduates to create jobs, rather than only seeking for jobs (Annual Report of Malaysian Education Blueprint 2013-2025, 2014). Therefore, this study aimed to investigate the significant predictors of university student's entrepreneurial mindset.

\subsection{Research Questions of the Study}

1) What is the level of entrepreneurial mindset among UPM students?

2) What is the level of each dimension of self-entrepreneurial competencies in developing entrepreneurial mindset among UPM students?

3) What is the relationship between dimensions of self-entrepreneurial competencies with entrepreneurial mindset?

4) Is there any relationship between self-entrepreneurial competencies with entrepreneurial mindset?

5) What are the predictors of entrepreneurial mindset?

\section{LITERATURE REVIEW}

An enterprising mindset is about having a way of thinking, which sees opportunities, rather than barrier, that sees possibilities rather than failure and wants to do something to make a difference rather than sit and complain about the problems (Souitaris, et al., 2007; Osterbeek, et al., 2010). While selfentrepreneurial competencies are defined as "cluster of associated knowledge, attitudes, and skills which an entrepreneur must obtain through managerial training and development that will enable students to produce outstanding performance and maximize profit" (Inyang \& Enuoh, 2009, p. 3).

Numerous prior studies had been conducted to examine the successful entrepreneurs'characteristics (McCelland, 1961; Brockhaus, 1982; Begley \& Boyd, 1987; Lumpkin \& Dess, 1996; Kolvereid \& Moen, 1997). A number of characteristics are considered in almost each of these studies. However competencies can range from personality traits, individual motivations with specific skills and knowledge (McKinsey Global Institute, 2005). The ultimate goal of entrepreneurial education is to expand the level of self-entrepreneurial competencies among learners in terms of knowledge, skills and/or attitudes (Solesvik, et al., 2013; ASTEE, 2014).

While in this study, self-entrepreneurial competencies are categorized into thirteen competencies as stated below in Table 1.0.

Table1.0. Definition for each self-entrepreneurial competencies dimension

\begin{tabular}{|l|l|}
\hline $\begin{array}{l}\text { Dimension of self- } \\
\text { entrepreneurial competencies }\end{array}$ & Definition \\
\hline a) Scanning & $\begin{array}{l}\text { Scanning plays an important element in skimming for new information and } \\
\text { novel ideas to seek opportunities in establishing a successful business and } \\
\text { thriving career by browsing internet, listening to news, reading magazines } \\
\text { or trade publications and interacting with people. }\end{array}$ \\
\hline b) Connectedness & $\begin{array}{l}\text { Connectedness is the ability or skill of relating information, which is more } \\
\text { likely to practise what students had learnt and apply the knowledge they } \\
\text { acquire. }\end{array}$ \\
\hline c) Evaluation & $\begin{array}{l}\text { Evaluation is the aptitude or the capability of an entrepreneur to make a } \\
\text { rational choice in choosing the right opportunity and developing a growth- } \\
\text { orientated business. }\end{array}$ \\
\hline
\end{tabular}




\begin{tabular}{|c|c|}
\hline d) Risk Perception & $\begin{array}{l}\text { Rational or irrational belief held by an individual who takes the risk by } \\
\text { venturing into business, which has a high potential of loss or doing poorly. }\end{array}$ \\
\hline e) Risk Propensity & $\begin{array}{l}\text { Risk Propensity is the measure of an entity's willingness to take chances } \\
\text { and face the risk by seeing the possibility of starting a business. }\end{array}$ \\
\hline f) Core Self-evaluation & $\begin{array}{l}\text { Core self-evaluation encompasses the ability and confident of a person } \\
\text { who able to evaluate and control their own ability. }\end{array}$ \\
\hline $\begin{array}{l}\text { g) Entrepreneurial } \\
\text { knowledge }\end{array}$ & $\begin{array}{l}\text { Entrepreneurial knowledge is the ability to understand the role of } \\
\text { entrepreneurs, which focuses on 1) assessing the students' perceived } \\
\text { knowledge on how to gauge business opportunities, 2) the role and } \\
\text { function of entrepreneurs play in society, as well as 3) the various } \\
\text { prospective of entrepreneurial career options that exist. }\end{array}$ \\
\hline h) Creativity & $\begin{array}{l}\text { Creativity is the main ingredients for entrepreneurs to establish new ways } \\
\text { of the stimulating creative thinking through imaginative skill in order to } \\
\text { identify and discover business opportunities. }\end{array}$ \\
\hline i) Financial Literacy & $\begin{array}{l}\text { Successfully engagement in entrepreneurial activities requires an } \\
\text { entrepreneur to have the capability to understand financial statements and } \\
\text { budgets such as cash flow, return investment and etc. It is important that } \\
\text { the entrepreneur must at least have a basic understanding of the financial } \\
\text { concept in order to be trustworthy to external and internal stakeholders. }\end{array}$ \\
\hline j) Managing Ambiguity & $\begin{array}{l}\text { In order for entrepreneurial activities be successfully performed, it is } \\
\text { important for an entrepreneur to manage and cope with uncertainty and } \\
\text { ambiguity in the process of implementing and exploiting a business idea. }\end{array}$ \\
\hline k) Marshalling of Resources & $\begin{array}{l}\text { Marshalling of resources is known as the essence of entrepreneurship to } \\
\text { exploit business opportunity through the ability to assemble and organize } \\
\text { resources. }\end{array}$ \\
\hline l) Planning & $\begin{array}{l}\text { The focal point of planning is the ability of an entrepreneur to sketch and } \\
\text { structure the tasks by setting appropriate goals and thus, successfully } \\
\text { executing the strategic plans. }\end{array}$ \\
\hline m) Innovative Employee & $\begin{array}{l}\text { It is important for employees to think and act like entrepreneurs to realize } \\
\text { their innovative potential whereby it allows them to have the problem } \\
\text { solving skills to solve their problems in their own ways of doing. }\end{array}$ \\
\hline
\end{tabular}

Source: Adapted from Solesvik, et al., 2013; ASTEE, 2014.

Following an analysing on entrepreneurial mindset competency, Solesvik, et al., (2013) and ASTEE (2014) was adopted as the preferred measurement tool to measure predictors of entrepreneurial mindset among university students for this research.

\section{Methodology}

\subsection{Design and Sampling}

In this study, quantitative correlational design is used. This study was conducted at one of the public university in Malaysia. The sample size consist 366 students which were selected from four Faculty of Study, which are Faculty of Science, Forestry, Educational Studies and Human Ecology using simple random sampling.

\subsection{Instrument}

Entrepreneurial questionnaires are obtained from Solesvik, et al., 2013 which consist 15 items. Meanwhile, self-competencies instrument was based on ASTEE (2014) which consist of 64 items with 13 dimensions namely; (i) Scanning, (ii) Connectedness, (iii) Evaluation, (iv) Risk perception, (iv) Risk propensity, (v) Core self-evaluation, (vi) Entrepreneurial knowledge, (vii) Creativity, (viii) Financial literacy, (x) Managing ambiguity, (xi) Marshalling of resources, (xii) Planning and (xiii) Innovative Employee. The response are modified by researcher into five point-Likert scale range from strongly disagree (1) to strongly agree (5). The questionnaires are modified to suit Malaysian culture and entrepreneurial practice.

\subsection{Validity and Reliability}

The instruments indicated overall excellent Cronbach $\alpha$ value for entrepreneurial mindsets $(\alpha=.931$ and self-competencies $(\alpha=.961)$ as supported by the George $\&$ Mallery $(2001$, p. 127) rule of thumb, therefore the instruments are accepted for consideration in this study. Students' participation was voluntary. 


\subsection{Data Analyses}

The level of entrepreneurial mindset and self- entrepreneurial competencies was based on the mean score obtained from descriptive analysis. The level of entrepreneurial mindset among UPM students is calculated based on Gravetter \& Wallnau, (2009) formula that was classified into three levels namely; low level (1.000 - 2.339), moderate level $(2.34-3.669)$ and high level $(3.67-5.00)$. Pearson correlational analysis was conducted to determine the correlation between entrepreneurial mindsets and self-competencies to measure significance relationship between two or more variables. Finally, multiple regressions was used to explore the influence of entrepreneurial mindsets on selfcompetencies. Preliminary analyses was conducted to check normality and linearity of the sample showed that scores were approximately normally distributed with a skewness of $.0195(\mathrm{SE}=.128)$ and a kurtosis of -.139 $(\mathrm{SE}=.254)$. All data collected were analysed by using the Statistical Package for Social Science (SPSS) Version 21.0.

\section{FINDINGS}

\section{RQ 1: What is the level of entrepreneurial mindset among UPM students?}

Mean scores, standard deviations and level of entrepreneurial mindset and self-entrepreneurial competencies are presented in Table 1.1. All the variables were normally distributed, as the mean rating scale for each variable is approximately 3.0 midpoint on the rating scale. The entrepreneurial mindset indicated that moderate level with mean score is 3.30 and standard deviation is .73. The result indicated that the students' entrepreneurial mindset development is sensible and modest. It clearly stated that students are still lacking in establishing their own firm and problem solving skills. Similarly, the level of self-entrepreneurial competencies showed moderate level with mean score is $3.58(\mathrm{SD}=.52)$. It clearly indicated that the progress of self- entrepreneurial competencies skills in students deficient in term of considering entrepreneurial as a career option, finding possibilities and seeking for new ideas.

Table1.1. Mean and standard deviations entrepreneurial mindset and self-entrepreneurial competencies

\begin{tabular}{|l|l|l|l|}
\hline Item & Mean & SD & Level \\
\hline Entrepreneurial mindset & 3.30 & .73 & Moderate \\
\hline Self-entrepreneurial competencies & 3.58 & .52 & Moderate \\
\hline
\end{tabular}

Source: Developed for this Research

RQ 2: What is the level of each dimension of self-entrepreneurial competencies in developing entrepreneurial mindset among UPM students?

The level of each dimension of self-entrepreneurial competencies in developing entrepreneurial mindset among UPM students based on the descriptive statistic result as shown in Table 1.2. The result of this study showed that the dimension of self-entrepreneurial competencies, which are Scanning, Core Self-evaluation, Entrepreneurial Knowledge, Marshalling of Resources, Planning and Innovative Employee showed high level followed by Connection, Evaluation, Risk Perception, Risk Propensity, Creativity, Financial Literacy and Managing Ambiguity showed moderate level. These competencies are described as the underlying characteristics in developing entrepreneurial mindset among UPM students, which result in effective actions and performances for an entrepreneurial mindset.

Table1.2. Level of each dimension of self-entrepreneurial competencies in developing entrepreneurial mindset

\begin{tabular}{|l|l|l|l|l|}
\hline No. & Dimension of self- entrepreneurial competencies & Mean Score & SD & Level \\
\hline 1 & Scanning & 3.73 & .61 & High \\
\hline 2 & Connection & 3.35 & .73 & Moderate \\
\hline 3 & Evaluation & 3.51 & .65 & Moderate \\
\hline 4 & Risk Perception & 3.43 & .76 & Moderate \\
\hline 5 & Risk Propensity & 3.51 & .79 & Moderate \\
\hline 6 & Core Self-evaluation & 3.92 & .63 & High \\
\hline 7 & Entrepreneurial Knowledge & 4.26 & .64 & High \\
\hline 8 & Creativity & 3.60 & .66 & Moderate \\
\hline 9 & Financial Literacy & 3.31 & .89 & Moderate \\
\hline 10 & Managing Ambiguity & 3.51 & .71 & Moderate \\
\hline 11 & Marshalling of Resources & 3.71 & .68 & High \\
\hline 12 & Planning & 3.67 & .73 & High \\
\hline 13 & Innovative Employee & 4.01 & .72 & High \\
\hline
\end{tabular}

Source: Developed for this Research 
RQ 3: What is the relationship between each dimension of self-entrepreneurial competencies with entrepreneurial mindset?

The correlation matrix between dependent variable (entrepreneurial mindset) and independent variables (self- entrepreneurial competencies) are exhibited in Table 1.3. Findings also indicated statistically significant correlations among all the 13 dimensions of self- entrepreneurial competencies with entrepreneurial mindset based on Hinkle, Wiersma \& Jurs (2003) Rule of Thumb.

Table1.3. Relationship between each dimension of self-entrepreneurial competencies with entrepreneurial mindset

\begin{tabular}{|l|l|l|}
\hline No. & Dimension of self- entrepreneurial competencies & r \\
\hline 1. & Scanning & $.576^{* * *}$ \\
\hline 2. & Connection & $.526^{* *}$ \\
\hline 3. & Evaluation & $.597^{* * *}$ \\
\hline 4. & Risk perception & $.281^{* * *}$ \\
\hline 5. & Risk propensity & $.753^{* *}$ \\
\hline 6. & Core self-evaluation & $.345^{* *}$ \\
\hline 7. & Entrepreneurial knowledge & $.328^{* *}$ \\
\hline 8. & Creativity & $.570^{* *}$ \\
\hline 9. & Financial literacy & $.544^{* *}$ \\
\hline 10. & Managing ambiguity & $.492^{* *}$ \\
\hline 11. & Marshalling of resources & $.473^{* *}$ \\
\hline 12. & Planning & $.571^{* *}$ \\
\hline 13. & Innovative Employee & $.457^{* *}$ \\
\hline
\end{tabular}

*. Correlation is significant at the 0.05 level (2-tailed).

**. Correlation is significant at the 0.01 level (2-tailed).

Source: Developed for this Research

RQ 4: Is there any relationship between self-entrepreneurial competencies with entrepreneurial mindset?

Correlation analysis was performed to determine the relationship between entrepreneurial mindset and self-competencies. Based on Table 1.4, there is high positivecorrelation between entrepreneurial mindset and self-entrepreneurial competencies $(\mathrm{r}=.717, \mathrm{p}<.05)$ based on Hinkle, Wiersma \& Jurs (2003) Rule of Thumb.

Table1.4. Correlation between self-entrepreneurial competencies and entrepreneurial mindset.

\begin{tabular}{|l|l|l|l|}
\hline Variables & & Entrepreneurial mindset & Self-competencies \\
\hline Entrepreneurial mindset & Pearson Correlation & 1 & $.717^{* *}(.000)$ \\
\hline Self-competencies & Pearson Correlation & $.717 * *(.000)$ & 1 \\
\hline
\end{tabular}

*. Correlation is significant at the 0.05 level (2-tailed).

**. Correlation is significant at the 0.01 level (2-tailed).

Source: Developed for this Research

RQ 5: What are the predictors of entrepreneurial mindset?

The findings from this study further clarifies that, the dimension Risk Propensity in the selfcompetencies received the strongest weight in the prediction (Standardized $\beta=.562, p<.05$ ), followed by Creativity (Standardized $\beta=.155, p<.05$ ) and Planning (Standardized $\beta=.571$, $p<.05)$ as portrayed in Table 1.5. These three variables showed statistically significant relationship in making a significant unique contribution to the prediction of entrepreneurial mindset. It can be concluded that $33.5 \%$ of the variance in self- entrepreneurial competencies can be explained by entrepreneurial mindset. However, there are still $66.5 \%$ variation of entrepreneurial mindset can be explicated by other variables which is not carried out in this research. The regression analysis showed that self-competency was partially related to entrepreneurial mindset. This finding highlights the sense of learners in seeing potential of starting and entrepreneur business. This study makes a novel contribution by evaluating student self-entrepreneurial competencies to bear uncertainty when the outcome is not known. 
Table1.5. Estimates of Coefficients for Entrepreneurial Mindset

\begin{tabular}{|c|c|c|c|c|c|c|c|c|c|c|c|}
\hline \multirow{2}{*}{\multicolumn{2}{|c|}{ Model }} & \multicolumn{2}{|c|}{$\begin{array}{l}\text { Unstandardized } \\
\text { Coefficients }\end{array}$} & \multirow{2}{*}{\begin{tabular}{|l|}
$\begin{array}{l}\text { Standardized } \\
\text { Coefficients }\end{array}$ \\
Beta
\end{tabular}} & \multirow[t]{2}{*}{$\mathbf{t}$} & \multirow[t]{2}{*}{ Sig. } & \multicolumn{3}{|c|}{ Correlations } & \multicolumn{2}{|c|}{\begin{tabular}{|l|} 
Collinearity \\
Statistics
\end{tabular}} \\
\hline & & $\mathbf{B}$ & \begin{tabular}{|l} 
Std. \\
Error
\end{tabular} & & & & \multirow[t]{2}{*}{\begin{tabular}{|l|} 
Zero- \\
order
\end{tabular}} & \multirow[t]{2}{*}{ Partial } & \multirow[t]{2}{*}{ Part } & \multirow[t]{2}{*}{ Tolerance } & \multirow[t]{2}{*}{ VIF } \\
\hline \multirow[t]{14}{*}{1} & (Constant) & .323 & .197 & & 1.637 & .103 & & & & & \\
\hline & MeanScanning & .083 & .053 & .070 & 1.562 & .119 & .576 & .083 & .047 & .453 & 2.206 \\
\hline & MeanConnection & .059 & .048 & .059 & 1.224 & .222 & .526 & .065 & .037 & .389 & 2.569 \\
\hline & MeanEvaluation & .036 & .057 & .032 & .622 & .534 & .597 & .033 & .019 & .351 & 2.851 \\
\hline & MeanRiskPerception & -.053 & .032 & -.056 & -1.666 & .097 & .281 & -.088 & -.050 & .828 & 1.208 \\
\hline & MeanRiskPropensity & .513 & .039 & .562 & 13.000 & .000 & .753 & .570 & .394 & .492 & 2.034 \\
\hline & MeanCoreSelfEvaluation & -.145 & .044 & -.127 & -3.287 & .001 & .345 & -.173 & -.100 & .617 & 1.622 \\
\hline & MeanEntrepreneurialKnowledege & -.026 & .040 & -.023 & -.650 & .516 & .328 & -.035 & -.020 & .735 & 1.360 \\
\hline & MeanCreativity & .169 & .055 & .155 & 3.056 & .002 & .570 & .161 & .093 & .359 & 2.787 \\
\hline & MeanFinancialLiteracy & .084 & .036 & .103 & 2.306 & .022 & .544 & .122 & .070 & .460 & 2.173 \\
\hline & MeanManagingAmbiguity & .097 & .050 & .095 & 1.953 & .052 & .492 & .104 & .059 & .390 & 2.563 \\
\hline & MeanMarshalingResources & -.131 & .060 & -.123 & -2.205 & .028 & .473 & -.117 & -.067 & 296 & 3.382 \\
\hline & MeanPlanning & .136 & .054 & .136 & 2.511 & .012 & .571 & .133 & .076 & .314 & 3.182 \\
\hline & MeanInnovativeEmployee & .043 & .041 & .042 & 1.041 & .299 & .457 & .055 & .032 & .555 & 1.801 \\
\hline
\end{tabular}

(Adjusted $\left.R^{2}=.665, F=56.383, p<.005\right)$

Source: Developed for this Research

\section{DisCUSSION}

It clearly indicates that successful entrepreneurs plan and prioritize work to ensure time is managed effectively (Wentzel \& Brophy, 2013). Hence, students able to work methodically and effectively by allocating time and resources as well taking necessary steps to skim through the challenges when the goal is not met. Besides that, entrepreneurial knowledge plays an important role with the aim of assessing students' perceived knowledge about business opportunities, the role of an entrepreneur in the society and seeking information for the entrepreneurial career path (Jones \& Iredale, 2010). Innovation and imagination is seen as an important element in university education particularly for undergraduate students (Barnett, 2011; Özkul, 2012). These skills require creativity and innovate to stimulate young entrepreneurs with the ability to think out of the box and discover business opportunities (Baron, 2012; Boyle, 2007).

Nevertheless, students are still lacking in term of financial literacy. Planning ability and financial literacy are interrelated entrepreneurial skill (Moberg, 2014). It is important for students to understand financial statements and budgets while planning and structuring their entrepreneurial activities (Delmar \& Shane, 2003). This finding highlighted that Creativity, Risk Perception, Risk Propensity, Evaluation and Managing Ambiguity showed students are lacking in exploiting the gaps and challenges in the market. It is important for students to facilitate these self-entrepreneurial skills to facilitate the integration and accumulation of fresh knowledge to stimulate an entrepreneurial mindset to discover the better opportunities (von Graebenitz, et al, 2010).

There is a positive significant relationship between entrepreneurial mindset and self-entrepreneurial competencies. This is due to self-competencies are determined by goal oriented, achievement and focused on proactive and creativity. Since the entrepreneurial mindset focus on innovativeness and risk-taking, however, it would not neglect the self-competencies skills. Significantly, "EE has a greater impact on the entrepreneurial mindset of young people, their intentions towards entrepreneurship, their employability and finally on their role in society and the economy" (European Union, 2012, p. 7). University students are more oriented to higher entrepreneurial mindset when they perceived risk-propensity. Prior research on the influence of personality on risk-taking behaviour revealed that risk propensity is determined by individual characteristics. For example, personality traits such as impulsivity, sensation-seeking, and low self-control generally exhibit risk-taking behaviour (Mishra \& Lalumière, 2011). The findings is also in line with Solesvik, et al., (2013) and ASTEE (2014) as their studies stated that students become more risk averse and realistic when they have higher entrepreneurial mindset. 


\section{CONCLUSIONS}

In a nutshell, University students have moderate entrepreneurial mindset. Similarly, the level of selfentrepreneurial competencies among university students showed moderate level. However, there is a positive significant relationship between entrepreneurial mindset and self-entrepreneurial competencies. This study revealed that risk propensity, creativity and planning received the strongest weight in the prediction. In a broad perspective, this study highlights the important of students to incorporated self-entrepreneurial competencies to exhibit entrepreneurial mindset.

\section{IMPLICATION OF THE FINDINGS}

The findings from this study are essential for practical reasons as university students should exhibit self-entrepreneurial competencies to evaluate and explore business opportunities in seeking their career path. This study can confirm a productive way to link educational intervention towards entrepreneurial learning outcomes. The underpinning principles of promoting self-entrepreneurial competencies among University students with the aim to develop entrepreneurial mindset among university students, seems to be able to result in formation of entrepreneurial identities, increased selfefficacy, increased uncertainty and ambiguity tolerance and increased self-insight.

\section{RECOMMENDATIONS}

To increase the pool of potential entrepreneurs among University students, Universities need to

- Construct a learning environment characterized by uncertainty and ambiguity as well as building on strong teamwork to develop student entrepreneurial mindset.

- Develop creativity, critical thinking, and curiosity among university students by providing seminars and training.

- Involving and encouraging university students to participate in business partnership.

- Recommend future research in entrepreneurial mindset in different settings - secondary schools and other universities across the country or within Malaysia.

\section{REFERENCES}

Arokiasamy, A. R. A. 2011. The Role of Higher Education in Promoting Entrepreneurship in Malaysia. Asian Journal of Management Research, 2 (1), 520-532.

ASTEE. (2014). How to Assess and Evaluate the Influence of Entrepreneurship Education. Ireland: Assessment Tools \& Indicators for Entrepreneurship Education (ASTEE).

Barnett, R. (2011). The Idea of the University in the Twenty-First Century: Where's the Imagination? Journal of Higher Education, 1 (2), 88-94.

Baron, R. 2012. Entrepreneurship: An Evidence-based Guide. Cheltenham, UK: Edward Elgar.

Begley, T.M. \& Boyd, D.P. (1987), "Psychological Characteristics Associated with Performance in Entrepreneurial Firms and Smaller Businesses. Journal of Business Venturing, 2, 79-93.

Biçerli, K. M. (2011). We Have to Re-structure Our Higher Education System in Parallel with the Developments in the Labor Market. Journal of Higher Education and Science, 1 (3), 122-127.

Boyle, T. J. (2007). A New Model of Entrepreneurship Education: Implications for Central and Eastern European Universities. Industry \& Higher Education, 16, 9-19.

Brockhaus, Sr., R. H. (1982), The Psychology of the Entrepreneur. In C. A. Kent, H. V. Karl, \& D. L. Sexton, Encyclopaedia of Entrepreneurship (pp. 39-57), New Jersey: Prentice-Hall.

Bruyat, C. \& Julien, P.-A. 2001. Defining the Field of Research in Entrepreneurship. Journal of Business Venturing, 16 (2), 165-180.

Delmar, F., \& S. Shane (2003). Does Business Planning Facilitate the Development of New Ventures?. Strategic Management Journal, 24, 1165-1185.

European Union. (2012). Effects and Impact of Entrepreneurship Programmes in Higher Education. Brussels: European Commission, DG Enterprise and Industry.

Fayolle, A., \& Klandt, H. (2006). International Entrepreneurship Education - Issues and Newness. Cheltenham: Edward Elgar Publishing Limited. 
George, D., \& Mallery, P. (2001). SPSS for Windows Step by Step: A Simple Guide and Reference 10.0 Update (3rd ed.). USA: Allyn \& Bacon.

Gravetter, F. J., \& Wallnau, L. B. (2009). Statistics for the Behavioral Sciences (8th ed.). USA: Wadsworth, Cengage Learning.

Gurol, Y. \& Atsan, N. (2006). Entrepreneurial Characteristics amongst University Students: Some Insights for Entrepreneurship Education and Training in Turkey. Education + Training, 48 (1): 25-38.

Hanapi, Z., \& Nordin, M. S. (2014). Unemployment among Malaysia Graduates: Graduates' Attributes, Lecturers' Competency and Quality of Education. Procedia - Social and Behavioral Sciences, 112 (Iceepsy 2013), 1056-1063.

Henry, B. (2003). Entrepreneurship Education in Kenya: A Reality or Plodding on? Proceedings from the First International Entrepreneurship Conference (pp. 23-24), Kenya.

Hinkle, D. E., Wiersma, W., \& Jurs, S. G. (2003). Applied Statistics for the Behavioral Sciences. Boston: MA: Houghton Mifflin.

Inyang, B. J., \& Enouh, R. O. (2009). Entrepreneurial Competencies: The Missing Links to Successful Entrepreneurship in Nigeria. International Business Research, 2 (2), 62-71.

Israel, K. J., \& Johnmark, D. R. (2014). Entrepreneurial Mind-Set among Female University Students: A Study of University of Jos Students, Nigeria, Chinese Business Review, 13 (5), 320-332.

Jones, B., \& Iredale, N. 2010. Enterprise Education as Pedagogy. Education + Training, 52 (1), 7-19.

Kolvereid, L., \& Moen, O. 1997. Entrepreneurship among Business Graduates: Does a Major in Entrepreneurship Make a Difference? Journal of European Industrial Training, 21 (4/5): 154160.

Lackéus, M. 2016. A 'Value' and 'Economics' Grounded Analysis of Six Value Creation Based Entrepreneurial Education Initiatives. Conference paper for 3E ECSB Entrepreneurship Education Conference (1-13 May 2016). Leeds, UK.

Lackéus, M. 2013. Developing Entrepreneurial Competencies - An Action-Based Approach and Classification in Education (Published Thesis). Licentiate Thesis, Chalmers University of Technology.

Lackéus, M. \& Williams Middleton, K. 2015. Venture Creation Programs - Bridging Entrepreneurship Education and Technology Transfer. Education + Training, 57 (1), 48-73.

Lumpkin, G. T. \& Dess, G. G. (1996). Clarifying the Entrepreneurial Orientation Construct and Linking it to Performance. Academy of Management Review, 21, 135-172.

Malaysian Education Blueprint Annual Report 2013 (2014). Malaysian: Ministry of Education Malaysia. Retrieved March 9, 2016 from http://www.padu.edu.my/files/AR/PADU_AR_2013_ ENG.pdf

McClelland, D. C. (1961), The Achieving Society. New York: Martino Fine Books.

McKinsey Global Institute (2005). The Emerging Global Labor Market. Part 1 - the Demand for Offshore Talent in Services, Retrieved April 12, 2016, from Executive Summary: htpp://www.mckinsey.com/mgi/publications/emerginggloballabormarket/index.asp

Mishra, S., \& Lalumière, M. L. (2011). Individual Differences in Risk-propensity: Associations between Personality and Behavioral Measures of Risk. Personality and Individual Differences, 50 (6), 869-873.

Moberg, K. 2014. Assessing the Impact of entrepreneurship Education: From ABC to PhD. (Published PhD Dissertation). Copenhagen Business School, Department for Strategy \& Globalization.

NEAC. 2010. New Economic Model for Malaysia Part 1. Malaysia: National Economic Advisory Council (NEAC).

Ooi, Y. K., Selvarajah, C., \& Meyer, D. 2011. "Inclination Towards Entrepreneurship among University Students: An Empirical Study of Malaysian University Students. International Journal of Business and Social Science, 2 (4), 206-220.

Oosterbeek, H., van Praag, M., \& Ijsselstein, A. 2010. The Impact of Entrepreneurship Education on Entrepreneurship Skills and Motivation. European Economic Review, 54 (3): 442-454. 
Othman, M. N., Ghazali, E., \& Cheng, O. C. (2005). Demographics and Personal Characteristics of Urban Malaysian Entrepreneurs: An Ethnic Comparison. International Journal of Entrepreneurship and Innovation Management, 5 (6), 421-440.

Özkul, T. (2012). Jump Starting Innovation in University Education. Journal of Higher Education, 2 (1), 20-27.

The Malaysia Education Blueprint 2013-2025. (2012). Malaysia: Ministry of Education.

Solesvik, M., Westhead, P., Matlay, H., \& Parsyak, V. (2013). Entrepreneurial Assets and Mindsets, Education + Training , 55 (8/9), $748-762$.

Souitaris, V., Zerbinati, S., \& Al-Laham, A. 2007. Do Entrepreneurship Programmes Raise Entrepreneurial Intention of Science and Engineering Students? The Effect of Learning, Inspiration and Resources. Journal of Business Venturing, 22 (4), 566-591.

Sözen, F. (2005, March 10). Is an Entrepreneurial Mindset Something You Can Teach and Learn?. Retrieved April 12, 2016, from JA Europe: http://www.jaeurope.org/blog/350-ee-hub-eu/8-is-anentrepreneurial-mindset-something-you-can-teach-and-learn.html

von Graevenitz, G., Harhoff, D., \& Weber, R. (2010), The Effects of Entrepreneurship Education, Journal of Economic Behavior \& Organization, 76 (1), 90-112.

Wentzel, K. R., \& Brophy, J. E. 2013. Motivating Students to Learn. USA: Routledge.

Wu, Wen-Wei. 2009. A Competency-based Model for the Success of an Entrepreneurial Start-up. WSEAS Transactions on Business and Economics, 6 (6), 279-291.

\section{AUTHORS' BIOGRAPHY}

Professor Dr. Zaidatol Akmaliah Lope Pihie is a professor at the Faculty of Educational Studies, Universiti Putra Malaysia. She has served in UPM since 1981. She graduated from Southern Illinois University - Carbondale, USA. She completed her Ph.D degree in 1992 and was promoted as Associate Professor in 1997 and offered as a full professor in 2003. From April 2001 to November 2002, she was appointed as the head of education department, as Deputy Dean of Faculty of Education from November 2002 to November 2005 and appointed as Deputy Dean (Research and Graduate Studies) from September 2010 to September 2012. She was also a Senate member in April 2005 to March 2008, and July 2011 to June 2014. Her areas of specializations are in entrepreneurship education, leadership and educational management as well as teaching methodology. She has presented and published a number of academic papers overseas and locally within her area of interest. She supervises $30 \mathrm{Ph}$.D students and 18 had graduated. She is actively involved in research activities. Her researches are mostly related to her area of expertise. She had received 3 gold medals, 6 silver medals and 9 bronze medals from UPM through her research effort.

Keetanjaly Arivayagan always has a growing desire to contribute towards the education world. This has stimulated her to explore the ideal quality of school leadership, school management and entrepreneurship education together with the integration of creativity and problem solving skills. Her passion and strong determination has encouraged her to persuade her studies in Master of Education specializing Educational Administration in University Putra Malaysia (UPM), which is one of the top public universities in Malaysia. The findings of this study would be very useful in civilizing and sustaining the quality of university and entrepreneurship education. 